\title{
The Arabidopsis Spontaneous Cell Death1 gene, encod- ing a $\zeta$-carotene desaturase essential for carotenoid biosynthesis, is involved in chloroplast development, photoprotection and retrograde signalling
}

Haili Dong ${ }^{1,2, *}$, Yan Deng ${ }^{1,2, *}$, Jinye $\mathrm{Mu}^{1}$, Qingtao $\mathrm{Lu}^{3}$, Yiqin Wang ${ }^{1}$, Yunyuan $\mathrm{Xu}^{3}$, Chengcai Chu ${ }^{1}$, Kang Chong ${ }^{3}$, Congming $\mathrm{Lu}^{3}$, Jianru $\mathrm{Zuo}^{1}$

Cell Research (2007) 17:575. doi: 10.1038/cr.2007.51; published online 14 June 2007

Correction to: Cell Research (2007) 17:458-470. doi:10.1038/cr.2007.37; published online 30 April 2007

The first two authors contributed equally to this work, which was missed in the footnote. "chlorophy ll" should be "chlorophyll" in Figure 4.

The correct forms are as follows:

*These two authors contributed equally to this work.

Correspondence: Jianru Zuo

Fax: +86-10-6487 3428

E-mail: jrzuo@genetics.ac.cn

Received 8 March 2007; revised 10 March 2007; accepted 12 March 2007; published online 30 April 2007
Figure 4

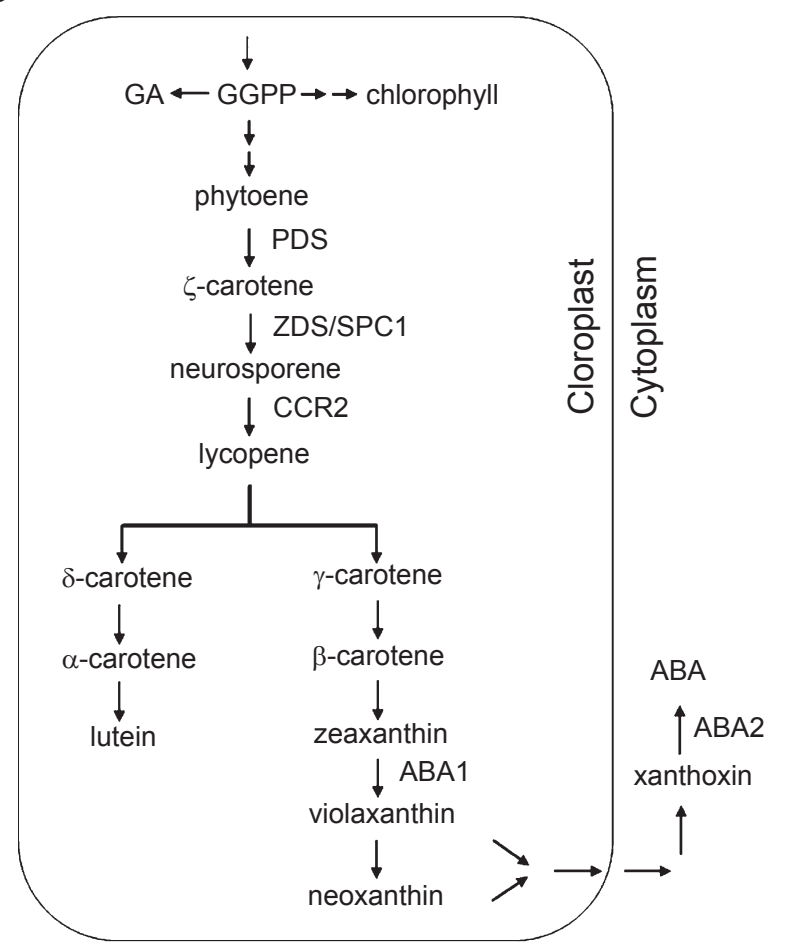

